Wahidah, F., \& Adam, P. (2019). Cognitive Behavior Therapy untuk Mengubah Pikiran Negatif dan Kecemasan pada Remaja. Indigenous: Jurnal Ilmiah Psikologi, 3(2). 57-69. doi:https://doi. org/10.23917/indigenous.v3i2.6826

\title{
Cognitive Behavior Therapy untuk Mengubah Pikiran Negatif Dan Kecemasan Pada Remaja
}

\author{
Fatin Rohmah Nur Wahidah ${ }^{1}$,Patricia Adam ${ }^{2}$ \\ Fakultas Psikologi Universitas Indonesia ${ }^{12}$ \\ fatin.nw@gmail.com ${ }^{1}$
}

\begin{abstract}
Parents are having role as the main significant others in a family for children. The way how parents treat their children will form children's self-esteem. Parents who compare their children with their siblings and continually emphasize their weakness, it can reduces children's self-esteem. Stepping into adolescents, children will find another social environment beside family and experiences which affecting the growth of children's self-esteem too. A low-self-esteem adolescent mostly look at themselves negatively. Subject in this study is an adolescent, 19 years old. Despite her superior IQ, healthy body, well-off family, and good GPA, her low-self-esteem makes the subject feel worthless and negative-outlook on herself. To help improving subject's self-esteem, cognitive behavior therapy (CBT) is considered as an appropriate approach. This study was aimed at find out effectiveness of CBT in helping subject to change the thoughts, beliefs, and negative emotions. Qualitative methods are used to analyze the intervention process. The results indicate that $C B T$ is effective to change negative thoughts, beliefes, and anxiety the subject. This finding can strengthen evidence of effectiveness CBT in changing one's thoughts and beliefs. Techniques that isused in CBT also proved can be used for adolescent with low self-esteem.
\end{abstract}

Keywords: adolescent, cognitive behavior therapy, self-esteem

Abstraksi. Orang tua berperan sebagai significant others dalam keluarga bagi anak. Cara orang tua memperlakukan anak dapat mempengaruhi self-esteem anak. Orang tua yang membandingkan anak dengan saudaranya dan terus menerus menyoroti kekurangan anak, akan dapat menurunkan selfesteem anak. Menginjak remaja, anak akan bertemu dengan lingkungan sosial lain selain keluarga dan mendapat banyak pengalaman yang juga mempengaruhi self-esteem anak. Remaja dengan selfesteem yang rendah akan memandang dirinya secara negatif. Subjek dalam penelitian ini adalah seorang mahasiswa, berusia 19 tahun. Meski memiliki IQ superior, fisik yang sehat, keluarga yang berkecukupan, dan nilai IPK yang tergolong baik, rendahnya self-esteem yang dimiliki membuat subjek merasa tidak berharga dan memiliki pandangan negatif tentang dirinya.

Kata kunci: cognitive behavior therapy, remaja, self-esteem

\section{PENDAHULUAN}

Pengasuhan dimaknai sebagai proses membangun hubungan orang tua dengan anak sejak masa kanak-kanak (Mogonea \& Mogonea, 2014; Nurmi \& Pullianinen, 1991; dalam Mulyadi, Rahardjo, \& Basuki, 2016). Secara umum, terdapat dua elemen penting terkait pengasuhan yang dilakukan orang tua kepada anak, yaitu demandingness dan responsiveness. Demandingness merujuk pada sejauh mana orang tua dalam pengasuhannya membuat pengawasan, tuntutan kedewasaan anak, upaya pendisiplinan, dan pengendalian perilaku anak 
yang tidak taat. Sedangkan responsiveness mengacu pada sejauh mana orang tua menunjukkan kehangatan, penerimaan, serta dukungan kepada anak (Baumrind, 1991 dalam Sartaj dan Aslam, 2010). Berdasarkan dua konstruk tersebut, terdapat empat gaya pengasuhan yang dapat diidentifikasi (Baumrind, 1991; Lamborn, Mounts, Steinberg, \& Dornbusch, 1991; Maccoby \& Martin, 1983; Musitu \& García, 2004; Steinberg, Lamborn, Darling, Mounts, \& Dornbusch, 1994; Villalobos et al., 2004, dalam Martínez \& García, 2007), yaitu authoritative (otoritatif), indulgent (memanjakan), authoritarian (otoriter), dan neglectful (pengabaian). Menurut Davies, Cummings, dan Winter (2004, dalam Sartaj \& Aslam, 2010), gaya pengasuhan yang orang tua memiliki dampak yang signifikan pada perilaku anak. Dari beberapa penelitian ditemukan bahwa orang tua yang menunjukkan kepedulian, perhatian, empati, dan dukungan kepada anakanaknya, berdampak pada self-esteem anak yang positif (Parker \& Benson, 2004; Trumpeter, Watson, O'Leary, \& Weathington, 2008; dalam Mulyadi, Rahardjo, \& Basuki, 2016). Sementara anak-anak yang merasa ditolak oleh orang tuanya menunjukkan adanya self-esteem yang rendah, ketidakstabilan emosi, bahkan dapat mengakibatkan hal lain yang lebih negatif, jika dibandingkan dengan anak yang merasa diterima oleh orang tua mereka (Palmer, \& Hollin, 2000; Rohner, \& Britner, 2002; Russ, Heim, \& Westen, 2003; Barnow, Lucht, \& Freyberger, 2005, dalam Sartaj \& Aslam, 2010).

Orang tua yang kurang mau mendengarkan, menerima, dan memberi kehangatan pada anaknya dapat dicirikan sebagai gaya pengasuhan otoriter, dimana orang tua memiliki demandingness yang tinggi namun responsiveness rendah (Cheryl, Marsiglia, Walczyk,Buboltz, \& Diana, 2005 dalam Sartaj \& Aslam, 2010). Gaya pengasuhan ini cenderung dinilai negatif oleh beberapa literatur karena dampak negatif yang ditimbulkan selama perkembangan anak (Cheryl, Marsiglia, Walczyk,Buboltz, \& Diana, 2005; Peterson, \& Hann, 1999; Stafford, \& Bayer, 1993, dalam Sartaj \& Aslam, 2010). Penelitian yang dilakukan pada anak usia prasekolah menunjukkan bahwa anak yang terpapar pengasuhan otoriter cenderung tidak bahagia, memiliki masalah sosial, agresif, dan mengalami kesulitan dalam mengaturemosi (Hart, Newell, \& Olsen, 2003, dalam Sartaj \& Aslam, 2010). Penelitian lain juga mengungkapkan bahwa gaya pengasuhan otoriter seringkali berhubungan dengan self-esteem anak yang rendah, adanya kecemasan, dan kurangnya keterampilan sosial anak dengan teman sebaya (Cheryl, Marsiglia, Walczyk,Buboltz, \& Diana, 2005 dalam Sartaj \& Aslam, 2010). Ketika dihadapkan dengan remaja, orang tua dengan gaya pengasuhan ini cenderung membatasi dan mengontrol remaja serta menjalin komunikasi verbal yang terbatas dengan mereka. Hasil penelitian Baumrind (1991, dalam Sartaj \& Aslam, 2010) menunjukkan bahwa gaya pengasuhan ini berkorelasi dengan perilaku sosial remaja yang tidak kompeten dan persepsi diri remaja yang negatif. Sejalan dengan hal tersebut, penelitian dari Altaf (2002, dalam Sartaj \& Aslam, 2010) menemukan bahwa remaja dengan orang tua otoriter seringkali cemas pada hubungan sosial atau pertemanan, kurang bisa beradaptasi, memiliki kemampuan komunikasi yang buruk, dan self-esteem yang rendah. Selain itu, remaja dengan orang tua otoriter memiliki prestasi akademik dan self-esteem yang paling buruk jika dibandingkan dengan anak yang memiliki orang tua dengan gaya pengasuhan lain (Martínez \& García, 2007).

Pada berbagai komponen dalam diri, seperti fisik, emosi, sosial, psikologis, dan perilaku, seseorang akan membuat evaluasi atas keberhargaan dirinya. Istilah ini sering disebut para ahli sebagai self-esteem. Mruk (2006) merangkum beberapa pendapat tokoh terkait self-esteem dan membaginya dalam tiga pandangan. Pertama, pandangan dari James (1890), self-esteem sebagai kompetensi diri, menegaskan bahwa kegagalan dan keberhasilan seseorang pada hal yang dianggap penting, akan membetuk self-esteem yang negatif maupun positif. Kedua, pandangan self-esteem sebagai keberhargaan diri dari Rosenberg (1965), menyatakan bahwa self-esteem sebagai suatu sikap yang didasarkan pada persepsi seseorang 
atas perasaan seberapa berharga dirinya sebagai individu. Seseorang yang merasa bahwa dirinya 'cukup baik' akan memiliki self-esteem yang positif, dan sebaliknya. Ketiga, pandangan Branden (1969) yang menjelaskan bahwa selfesteem merupakan hubungan antara kompetensi diri (kegagalan dan keberhasilan seseorang) dengan perasaan berharga. Penelitian terkini cenderung merujuk pada pandangan ketiga. Adanya interaksi elemen kompetensi diri dan keberhargaan diri inilah yang menghasilkan selfesteem individu (Tafarodi \& Milne, 2002, dalam Mruk, 2006). Santrock (2011) menambahkan, pembentukan self-esteem terjadi melalui proses panjang melalui interaksi seseorang dengan lingkungannya (keluarga, teman, dan orang lain yang bermakna). Oleh karena itu, dapat disimpulkan bahwa self-esteem merupakan evaluasi keseluruhan individu atas keberhargaan dirinya sebagai hasil interaksi antara kompetensi diri dan keberhargaan diri yang diperoleh melalui serangkaian proses panjang antara individu dan lingkungannya.

Keluarga merupakan lingkungan sosial yang pertama bagi anak, dimana orang tua merupakan significant others yang utama. Perilaku yang diberikan orang tua terhadap anak akan membentuk self-esteem anak (Coopersmith, dalam Mruk 2006). Ketika orang tua berbicara dengan cara yang positif kepada anak, memberikan emosi dan pengalaman positif, dan memberikan penjelasan ketika berkonflik dengan anak, anak akan memiliki self-esteem yang positif. Sementara jika orangtua menuntut hal yang terlalu tinggi sehingga tidak menerima anak apa adanya, maka anak juga akan menolak dirinya. Pun ketika orang tua membandingkan anaknya dengan kakak/adiknya, menyoroti kelemahan anak secara terus menerus hingga menimbulkan pengalaman dan emosi negatif, hal ini akan menurunkan self-esteem anak (Newman \& Newman, 2015).

Seiring berjalannya waktu, anak terus bertumbuh. Semakin banyak pula orang di lingkungan yang mempengaruhi pembentukan self-esteem-nya, termasuk kelompok teman sebayanya. Seseorang yang merasa dirinya dihormati, diterima, dan diperlakukan dengan baik akan cenderung terbentuk self-esteem yang tinggi. Sebaliknya, seseorang yang merasa diremehkan, ditolak, dan diperlakukan buruk akan cenderung terbentuk self-esteem yang rendah (Coopersmith, 1967).

Seseorang dengan self-esteem rendah akan sangat memperhatikan perlakuan yang merendahkan dirinya. Ia juga merasa bahwa umpan balik negatif dari orang lain merupakan hal yang menyakitkan baginya (Newman \& Newman, 2015). Ia lebih banyak berfokus pada informasi negatif tentang dirinya dan mengabaikan hal positif dari dirinya. Cara berpikirnya cenderung kaku/tidak fleksibel dan ia sering mengalami kecemasan (Coopersmith \& Epstein, dalam Mruk, 2006). Dalam berpendapat, ia akan bersikap sebaliknya dari orang yang memiliki self-esteem yang tinggi, yaitu aktif dan mampu mengekspresikan pendapatnya, merasa percaya diri dengan pandangannya, dan jujur dalam berpendapat (Coopersmith, 1967 dalam Guindon, 2010). Ketika menemukan situasi yang menantang, seseorang dengan selfesteem tinggi akan menunjukkan kepercayaan diri dan harapan positifnya. Biasanya, ia pun tidak akan kecewa jika belum berhasil mencapai tujuannya. Misalnya ketika menghadapi tekanan akademik, ia akan mampu menghadapi tantangan dan tekanan akademik tersebut dengan tidak mengeluh, aktif berpartisipasi dalam perilaku belajar yang baru, dan terus berusaha mencapai tujuannya (Chris, Pais, \& Senthil, 2012 dalam Acharya Pandey \& Chalise, 2017; Mulyadi, Rahardjo, \& Basuki, 2016). Sebaliknya, seseorang dengan self-esteem rendah akan menampilkan diri secara negatif, pesimis pada situasi baru yang menantang, dan memiliki ekspektasi pada masa depan yang cenderung rendah (Acharya Pandey \& Chalise, 2017).

Subjek dalam penelitian ini berinisial F. F merupakan klien Klinik Terpadu Fakultas Psikologi Universitas Indonesia. F menilai kehidupan keluarganya tidak harmonis. Ibunya kerap membatasi dan mengatur aktivitasnya sehari-hari. Ibunya cenderung menuntut hal-hal yang melebihi kemampuannya, termasuk dalam hal akademik.Sebaliknya, ayah F seringkali 'tidak nampak' berada di rumah dan kurang 
terlibat dalam pengasuhan. Komunikasi antara $\mathrm{F}$ dan keluarga pun cenderung minim dan kurang terbuka. Hal ini membuat $F$ tidak terbiasa mengungkapkan pikiran dan perasaannya dan lebih banyak menghadapi masalahnya sendiri. Ia pun lebih sering tampil sebagai pribadi yang tertutup. Dapat dikatakan, pengasuhan F didominasi oleh ibunya dibanding ayahnya dan mengarah pada gaya pengasuhan otoriter. Gaya pengasuhan otoriter ibunya dihadapi $\mathrm{F}$ sejak masa kanak-kanak hingga remaja akhir ini. Menurut Baumrind (1991, dalam Sartaj \& Aslam, 2010), gaya pengasuhan otoriter berkorelasi dengan perilaku sosial remaja yang tidak kompeten dan persepsi diri yang negatif. Penelitian dari Altaf (2002, dalam Sartaj \& Aslam, 2010) menambahkan bahwa remaja dengan orang tua otoriter seringkali cemas pada hubungan sosial atau pertemanan, memiliki kemampuan komunikasi yang buruk, dan memiliki self-esteem yang rendah.

Hubungan $\mathrm{F}$ dengan keluarga cenderung kurang hangat. $\mathrm{F}$ merasa tidak diterima apa adanya dan tidak cukup mendapat dukungan maupun kasih sayang. Karena itu, F kerap merasa kesepian dan kurang terpenuhi kebutuhan afeksinya. Newman dan Newman (2015) mengungkapkan bahwa salah satu hal yang mempengaruhi self-esteem yaitu perasaan akan kasih sayang. Ketika seseorang berpandangan bahwa dirinya tidak disayangi dan diabaikan, maka ia akan merasa dirinya tidak berharga (selfesteem rendah). Selain itu, penerimaan orang tua juga penting terhadap perkembangan self-esteem anak (Newman \&Newman, 2015; Coopersmith; Rosenberg, dalam Mruk 2006). Penerimaan yang dimaksud adalah kesediaan orang tua untuk melihat kelebihan dan kekurangan anak serta potensi dan keterbatasannya secara seimbang. Seorang anak yang tidak mendapat kehangatan dan penerimaan dari orang tua menjadi faktor yang menurunkan self-esteem anak (Kernis, 2003, dalam Mruk, 2006). Selain itu, ibu F kerap membandingkannya dengan saudaranya dan berkomentar bahwa $F$ tidak lebih baik dari saudaranya. Padahal orang tua yang sering mengkritik akan membuat anak memiliki self-esteem negatif (Mruk, 2006).
Dalam pergaulan dengan kelompok sebaya, F juga merasa mendapat pengalaman negatif, seperti: diremehkan, diberikan komentar negatif, tidak didengar pendapatnya, dan merasa kesulitan untuk memulai hubungan pertemanan. Hal tersebut semakin menguatkan penilaian negatif $F$ tentang dirinya. Meski $F$ tahu bahwa taraf kecerdasannya tergolong superior $(\mathrm{IQ}=131$, berdasarkan skala CFIT) dan memiliki banyak hal positif dalam dirinya, hal tersebut cenderung luput dari pandangannya. Ia lebih sering mengalami emosi negatif (seperti: cemas, sedih, kesepian, tidak percaya diri, pesimis) dan mempersepsikan dirinya secara negatif (gagal, tidak berharga, bodoh).

Berdasarkan asesmen yang dilakukan, diketahui bahwa sikap dan perilaku yang $\mathrm{F}$ tunjukkan mengarah pada karakteristik individu dengan self-esteem rendah. Keyakinan diri F adalah 'Saya tidak cukup baik'. Pikiran otomatis negatif yang muncul dalam dirinya antara lain; 'Saya tidak disayang orang tua', 'Apapun yang saya lakukan selalu salah di mata ibu', 'Saya tidak sepandai teman-teman', 'Saya tidak bisa lulus cumlaude'. Kemudian, situasi yang biasanya menjadi penyebab pikiran otomatis itu muncul adalah ketika ibu yang membandingbandingkan $F$ dengan saudaranya serta temannya yang berkomentar negatif yang mengatakan dia 'bodoh'. Dampak dari pikiran otomatis terhadap perasaan dan perilaku $\mathrm{F}$ adalah tidak percaya diri dan menilai dirinya gagal mencapai prestasi akademik yang diharapkan; F menganggap pencapaian akademik itu penting, namun ia merasa kesulitan menghadapi perkuliahannya saat ini sehingga tidak termotivasi dalam belajar; F cemas dan panik ketika ujian serta tidak fokus belajar. Self-esteem yang rendah pada F berpotensi menimbulkan masalah psikologis yang dapat mengganggu kehidupan pribadi, sosial, maupun akademis F. Oleh karena itu, intervensi kepada F dinilai perlu dilakukan.

Terdapat beberapa cara yang dapat dilakukan untuk meningkatkan self-esteem, salah satunya melalui pendekatan kognitif. Strategi kognitif paling umum dan dianggap paling efektif digunakan dalam berbagai rentang usia adalah cognitive behavioral therapy 
(CBT). Menurut stategi ini, perubahan selfesteem dapat terjadi ketika individu mengalami intervensi pada kognitif untuk merestrukturisasi proses evaluasi dirinya (Guindon, 2010). CBT membantu klien melihat bagaimana mereka menginterpretasi dan mengevaluasi apa yang terjadi saat ini di sekitar mereka dan dampak dari persepsinya tersebut pada pengalaman emosional mereka (Rector, 2010; Corey, 2009). Dalam CBT, terapis akan mengidentifikasi, bertanya, dan mengubah pikiran, sikap, asumsi, dan kepercayaan klien. Klien sendiri perlu menyadari bahwa cara pikirnya akan berkontribusi pada masalah emosi yang dimiliki, contohnya kecemasan. Cara untuk mengurangi masalah emosi tersebut adalah dengan mengidentifikasi pikiran yang mengganggu klien, melihat apa yang dipikirakan dan kenyataan yang terjadi, serta memposisikan atau menegakkan kembali 'pikiran yang lurus' dengan mempertimbangkan situasi dari berbagai sudut pandang (Rector, 2010; Corey, 2009).

CBT tidak bertujuan untuk mengajarkan pikiran positif sebagai solusi atas masalah klien, tetapi membuat klien menyadari dan dapat mengevaluasi pengalaman dan masalah yang ia miliki dari perspektif berbeda -positif, negatif, netral- sehingga mendapatkan kesimpulan dan solusi yang tepat atas masalahnya tersebut (Rector, 2010; Corey, 2009). Pendekatan CBT melibatkan beberapa teknik, seperti dialog sokratik, kolaborasi empiris, perdebatan kepercayaan irasional, pembentukan alternatif interpretasi, bermain peran, imajinatif, dan mengkonfrontasi kepercayaan yang keliru (Rector, 2010; Corey, 2009). Fennell \& Jenkins (2004, dalam Della 2012) menyebutkan bahwa terdapat tiga level kognisi yang berperan kepada rendahnya self-esteem yaitu: keyakinan negatif (core belief) mengenai diri sendiri, orang lain, maupun dunia, conditional dysfunctional assumptions berupa aturan dan asumsi yang dibuat untuk melindungi self-esteem, negative automatic thoughts (pikiran otomatis negatif) yang membuat self-esteem tetap rendah. Dalam proses terapi, terapis akan mengajarkan kepada klien cara mengidentifikasi kognitif yang rancu dan tidak berfungsi melalui proses evaluasi.
Corsini dan Wedding (2011) menjelaskan bahwa terdapat beberapa tahapan dalam pelaksanaan CBT. Pada sesi awal CBT biasanya dimaksudkan untuk membangun relasi dengan klien, menggali informasi penting (seperti: pengalaman masa lalu, situasi hidup saat ini, masalah psikologis yang ada, sikap terhadap terapi, motivasi mengikuti terapi), dan mengidentifikasi keluhan yang muncul. Terapis dapat membuat problem list yang mencakup simptom spesifik, perilaku, dan masalah yang menetap. Dari daftar tersebut kemudian dibuat prioritas, sebagai target intervensi. Pada sesi ini, klien pun dijelaskan bahwa tujuan utama terapi adalah untuk membuat klien belajar menjadi terapis bagi dirinya sendiri.

Sesi selanjutnya, klien diajak untuk memahami hubungan antara kognisi dan afek dari sudut pandang CBT serta bagaimana kognisi dapat mempengaruhi afek dan perilaku seseorang (Corsini \& Wedding, 2011). Pola interaksi antara keyakinan, pemikiran, perilaku, dan emosi mempengaruhi cara individu memproses informasi yang diperoleh. Proses informasi oleh individu dengan self-esteem rendah cenderung bias. Individu akan lebih memberikan perhatian dan mengingat pengalaman yang sesuai dengan keyakinan negatifnya dan melewatkan pengalaman yang sebenarnya dapat menentang keyakinan negatif tersebut. Intervensi terhadap self-esteem dengan CBT menuntut pasien untuk menyadari proses yang membuat keyakinan negatifnya berkelanjutan dan mempelajari cara untuk mengatasi hal ini (Fennell \& Jenkins, 2004, dalam Della 2012).

Pada sesi berikutnya, klien diajak untuk mengenal pola berpikirnya melalui pemeriksaan pikiran otomatis negatif. Saat klien dapat menantang pikiran negatifnya, klien mulai dapat mempertimbangkan asumsi/aturan dasar yang memunculkan pemikiran tersebut. Setelah asumsi/aturan dasar dikenali, terapi ditujukan untuk memodifikasi asumsi tersebut dengan mempertimbangkan keberfungsiannya bagi klien. Pada sesi-sesi selanjutnya, klien diberikan tanggung jawab lebih untuk mengidentifikasi masalah serta menemukan solusinya sendiri. Peran terapis berubah menjadi penasihat saat 
klien sudah mulai dapat menggunakan teknikteknik yang ada untuk menyelesaikan masalah. Terapi diterminasi saat tujuan sudah dicapai dan klien merasa dapat mempraktikkan kemampuan baru mereka secara mandiri (Corsini \& Wedding, 2011).

Penelitian ini bertujuan untuk mengetahui efektivitas CBT dalam mengubah pikiran, keyakinan diri, dan emosi subjek yang cenderung negatif menjadi lebih positif. Kemampuan kognitif $\mathrm{F}$ yang tergolong baik, kesadaran $\mathrm{F}$ atas masalah yang dihadapi, dan keinginannya untuk berubah, diperkirakan dapat membantunya menjalani proses intervensi ini dengan baik.

\section{METODE PENELITIAN}

Penelitian ini menggunakan metode kualitatif dengan pendekatan studi kasus tunggal, yang dilakukan selama satu bulan. Metode kualitatif ini dipilih karena peneliti ingin melihat proses perubahan pikiran dan perasaan subjek pada sebelum dan setelah mendapat intervensi CBT. Metode ini dianggap tepat digunakan untuk mencapai tujuan penelitian karena metode ini memungkinkan peneliti memperoleh pemahaman yang utuh dan terintegrasi mengenai fakta-fakta dalam kasus tersebut (Poerwandari, 2011). Jumlah subjek dalam penelitian ini berjumlah 1 orang $(n=1)$. Subjek merupakanseorang remaja perempuan berusia 19 tahun, anak ke tiga dari empat bersaudara, dan sedang menempuh pendidikan tinggi tingkat ketiga.

Metode pengumpulan datadalam penelitian ini diperoleh melalui observasi, wawancara, alat tes proyektif, dan pemberian lembar kerja tugas. Data wawancara yang diperoleh dalam penelitian ini direkam menggunakan tape recorder, kemudian ditulis kembali secara verbatim dan dikategorisasi dalam tema-tema. Setelah itu, peneliti menyimpulkan inti dari jawaban subjek.

Sebelum dilakukan intervensi, terdapat rangkaian kegiatan pra-intervensi yang dilakukan peneliti, yaitu membangun rapport kembali dengan subjek agar dapat saling bekerja sama selama intervensi. Selain itu, menginformasikan informed consent yang berisi informasi terkait tujuan, prosedur, tempat, dan waktu pelaksanaan intervensi serta kerahasiaan data subjek, guna mencapai kesepakatan dan komitmen menjalani intervensi.

Pelaksanaan intervensi CBT mengacu pada konsep Stallard (2002). Tidak ada batasan mutlak terkait materi dan jumlah sesi CBT yang harus diberikan menurut Stallard. Adapun lembar kerja dan materi dalam intervensi CBT ini dirangkum dari beberapa sumber (Stallard, 2002, Corsini \& Wedding, 2011, therapistaid. com, 2017, Della, 2012) meliputi: teori dan penelitian sebelumnya, serta materi workshop yang peneliti peroleh dari ahli untuk disesuaikan dengan karakteristik dan permasalahan subjek.

Dengan mempertimbangkan permasalahan subjek, kemampuan kognitif subjek, dan waktu pertemuan dengan subjek, peneliti merencanakan pemberian intervensi CBT dalam tiga sesi yang masing-masing berdurasi 60-120 menit. Pada sesi satu, terdiri dari beberapa bagian, yaitu psikoedukasi tentang cognitive model; mengidentifikasi core belief; mengidentifikasi distorsi kognitif; mengidentifikasi aturan dan asumsi; dan mengidentifikasi pikiran otomatis. Sesi dua adalah merestrukturisasi kognisi. Sesi tiga adalah aktivitas untuk menemukan aspek positif dalam diri dan kegiatan yang dapat menguatkan perilaku positif. Di setiap akhir sesi, subjek diberikan kesempatan untuk melakukan evaluasi sehingga diketahui insight yang subjek peroleh. Subjek juga diberikan tugas yang dikerjakan di rumah dan dibawa kembali saat sesi berikutnya. Tahap terakhir adalah evaluasi keseluruhan intervensi yang dilakukan sepekan setelah intervensi. Subjek diminta untuk menceritakan pengalaman dan kesan yang ia rasakan selama dan setelah intervensi. Subjek juga diminta untuk menceritakan penerapan teknik-teknik yang telah diajarkan selama intervensi dalam kehidupan sehari-hari. Gambaran rancangan intervensi ditunjukkan dalam tabel 1 . 
Tabel 1. Rancangan Intervensi

\begin{tabular}{|c|c|}
\hline Tujuan & Kegiatan \\
\hline \multicolumn{2}{|r|}{ Sesi 1 : Cognitive Model and Cognitive Distortions (60-120 menit) } \\
\hline $\begin{array}{l}\text { Mengetahui pola inter- } \\
\text { aksi pikiran, emosi, dan } \\
\text { perilaku }\end{array}$ & $\begin{array}{l}\text { - Terapis mempersilakan klien menjelaskan situasi hidup saat ini terkait masalah psi- } \\
\text { kologis yang dihadapi } \\
\text { - Terapis bersama klien membuat daftar prioritas masalah yang akan menjadi fokus } \\
\text { terapi berdasarkan simptom spesifik, perilaku, dan masalah yang menetap. } \\
\text { - Terapis menjelaskan pengaruh pikiran terhadap emosi dan perilaku hingga serta pen- } \\
\text { garuhnya terhadap keyakinan dasar dan distorsi koginitif }\end{array}$ \\
\hline $\begin{array}{l}\text { Mengidentifikasi core } \\
\text { belief(keyakinan dasar) }\end{array}$ & $\begin{array}{l}\text { - Terapis menjelaskan apa yang dimaksud dengan core belief } \\
\text { - Terapis menggali keyakinan dasar klien yang negatif tentang dirinya } \\
\text { Terapis menjelaskan dampak adanya keyakinan negatif yang memunculkan distorsi } \\
\text { kognitif }\end{array}$ \\
\hline $\begin{array}{l}\text { Mengidentifikasi distorsi } \\
\text { kognitif }\end{array}$ & $\begin{array}{l}\text { - Terapis memberikan pemahaman kepada klien mengenai distorsi kognitif dan berag- } \\
\text { am jenisnya } \\
\text { - Terapis meminta klien mengidentifikasi kesalahan-kesalahan berpikir yang dimiliki }\end{array}$ \\
\hline $\begin{array}{l}\text { Mengidentifikasi aturan } \\
\text { dan asumsi }\end{array}$ & $\begin{array}{l}\text { - Terapis bertanya apa yang klien ketahui tentang aturan dan asumsi. } \\
\text { - Terapis meminta klien menuliskan aturan dan asumis yang dimiliki klien selama ini, } \\
\text { yang menjadi panduan dalam bertingkah laku sehari-hari; jika... maka, harus... } \\
\text { - Terapis menanyakan aturan/asumsi mana yang menurut klien bermanfaat dan tidak } \\
\text { bermanfaat baginya }\end{array}$ \\
\hline $\begin{array}{l}\text { Mengidentifikasi pikiran } \\
\text { otomatis }\end{array}$ & $\begin{array}{l}\text { - Terapis meminta klien memikirkan saat dimana ia memiliki emosi negatif dalam satu } \\
\text { atau dua minggu terakhir ini; misalnya cemas, sedih, panik, tidak berharga. Lalu apa } \\
\text { yang dipikirkan pada waktu itu. } \\
\text { - Terapis menanyakan apa reaksi yang muncul akibat dari pikiran otomatis yang negatif } \\
\text { tersebut serta manfaat yang diperolehnya }\end{array}$ \\
\hline Tugas rumah & $\begin{array}{l}\text { - Klien diminta mempelajari kembali materi hari ini melalui lembar kerja } \\
\text { - 'Cognitive Model' dan 'Cognitive Distortions' } \\
\text { - Klien diberikan lembar 'Challenging Thought' untuk membantu menantang pikitan } \\
\text { negatif dalam dirinya }\end{array}$ \\
\hline $\begin{array}{l}\text { Evaluasi sesi } 1 \\
\text { - Mengetahui insight } \\
\text { yang klien dapatkan }\end{array}$ & $\begin{array}{l}\text { - Terapis meminta klien menyampaikan apa yang diperoleh dari sesi terapi yang diikuti } \\
\text { - Terapis mencatat perasaan dan cerita yang disampaikan klien }\end{array}$ \\
\hline
\end{tabular}

Sesi 2 : Cognitive Restructuring (60-120 menit)

Merestrukturisasi kognitif yang dimiliki

Tugas rumah

Evaluasi sesi 2

- Mengetahui insight yang klien dapatkan
- Terapis menanyakan kepada klien apakah sudah mengerjakan tugas rumah atau belum dan sejauh mana perubahan yang terjadi dalam dirinya

- Terapis memberi kesempatan kepada klien untuk menceritakan perasaan dan pikirannya terkait pikiran otomatis yang negatif serta aturan dan asumsi yang dimiliki

- Terapis menggunakan teknik-teknik yang dapat membantu klien mengevaluasi pikiran negatif yang dimiliki; pertanyaan sokratik dan mengajukan pertanyaan-pertanyaan kepada klien sebagai cara menemukan bukti dan mengevaluasi pikiran klien

- Terapis meminta klien memikirkan alternatif pikiran yang lebih positif dan membandingkannya dengan pikiran negatif yang sebelumnya.

- Hal yang sama juga dilakukan untuk menantang aturan dan asumi lama. Klien diminta membuat aturan dan asumsi baru yang lebih seimbang, realistis, dan fleksibel menggantikan aturan dan asumsi lamanya

- Terapis menjelaskan tugas klien dan memberi contoh pengerjaan pada lembar kerja 'Putting Thought on Trial'

- Klien diminta membuat catatan pikiran yang muncul pada beragam situasi beserta perasaan dan perilaku yang menyertai dalam lembar 'Thought Records'

- Klien diminta membuat catatan pikiran otomatis dan aturan/asumsi yang baru

- Terapis meminta klien menyampaikan apa yang diperoleh dari sesi terapi yang diikuti

- Terapis mencatat perasaan dan cerita yang disampaikan klien 
Sesi 3 : Akivitas Aspek Positif dalam Diri (60-120 menit)

\begin{tabular}{|c|c|}
\hline & Sesi 3 : Akivitas Aspek Positif dalam Diri (60-120 menit) \\
\hline $\begin{array}{l}\text { Aktivasi aspek positif } \\
\text { dalam diri } \\
\text { - Membantu klien } \\
\text { menemukan } \\
\text { aspek-aspek positif } \\
\text { dan kekuatan dalam } \\
\text { dirinya }\end{array}$ & $\begin{array}{l}\text { - Terapis menanyakan kepada klien apakah sudah mengerjakan tugas rumah atau } \\
\text { belum dan sejauh mana perubahan yang terjadi dalam dirinya } \\
\text { - Terapis meminta klien menceritakan perbedaan diri klien yang sekarang dan yang } \\
\text { dulu, terutama dalam mengandalkan kekuatan dirinya tersebut } \\
\text { - Terapis meminta klien menceritakan mimpinya di masa depan dan apa saja penca- } \\
\text { paian yang ia inginkan serta bagaimana cara ia mencapainya. } \\
\text { - Terapis melakukan review atas hal-hal positif dari klien. Klien dapat menambahkan } \\
\text { - jika perlu, terutama aspek-aspek yang berkaitan dengan pencapaian akademik. } \\
\text { - Terapis meminta klien menceritakan pengalaman pada masa lalu yang membuatnya } \\
\text { berubah dan dapat mengandalkan kekuatan dirinya }\end{array}$ \\
\hline $\begin{array}{l}\text { Aktivasi perilaku positif } \\
\text { Membantu klien } \\
\text { menemukan kegia- } \\
\text { tan yang menguat- } \\
\text { kan aspek positif } \\
\text { pada dirinya }\end{array}$ & $\begin{array}{l}\text { - Terapis mereview latihan relaksasi pernafasan yang telah diajarkan } \\
\text { - Terapis meminta klien menuliskan seluruh kegiatan yang membuatnya rileks, tenang, } \\
\text { nyaman, dan berpikir positif. } \\
\text { - Klien diminta untuk menghubungkan kegiatan-kegiatan tersebut dengan aspek positif } \\
\text { yang ada pada dirinya }\end{array}$ \\
\hline Tugas rumah & $\begin{array}{l}\text { - Klien diminta melakukan relaksasi yang telah diajarkan hingga pertemuan selanjutnya } \\
\text { - Klien diminta membuat cerita hidup yang membuatnya menemukan makna dari dir- } \\
\text { inya dalam lembar Life Story' } \\
\text { Klien membuat 'Gratitude Journal' dan 'Self-esteem Journal' selama sepekan atau hing- } \\
\text { ga pertemuan selanjutnya }\end{array}$ \\
\hline $\begin{array}{l}\text { Evaluasi sesi } 3 \\
\text { - } \quad \text { Mengetahui insight } \\
\text { yang klien dapatkan }\end{array}$ & $\begin{array}{l}\text { - Terapis meminta klien menyampaikan apa yang diperoleh dari sesi terapi yang diikuti } \\
\text { - Terapis mencatat perasaan dan cerita yang disampaikan klien } \\
\text { Evaluasi dan Asesmen Akhir (60-120 menit) }\end{array}$ \\
\hline $\begin{array}{l}\text { Evaluasi dan Asesmen } \\
\text { Akhir } \\
\text { - Mengevaluasi } \\
\text { keseluruhan sesi, } \\
\text { mendiskusikan hasil } \\
\text { intervensi, asesmen } \\
\text { akhir, dan terminasi }\end{array}$ & $\begin{array}{l}\text { - Terapis meminta klien menceritakan tentang efektivitas program intervensi, melipu- } \\
\text { ti: perubahan cara pandang, pemahaman akan diri, perbedaan sebelum dan sesudah } \\
\text { mengikuti intervensi, dan penerapan latihan yang diberikan di kemudian hari } \\
\text { - Terapis memberikan apresiasi kepada klien atas keberhasilan yang sudah dicapai sela- } \\
\text { ma mengikuti intervensi } \\
\text { Terapis menanyakan kepada klien tentang dan evaluasi secara keseluruhan sesi terapi }\end{array}$ \\
\hline
\end{tabular}

\section{HASIL DAN PEMBAHASAN}

Intervensi CBT yang dilakukan terbukti efektif untuk mengubah pikiran, keyakinan, dan emosi negatifyang dialami subjek menjadi lebih positif. Artinya, self-esteem subjek meningkat. Hal ini sejalan dengan penelitian yang dilakukan oleh Della (2012) yang menunjukkan bahwa CBT terbukti meningkatkan self-esteem pada mahasiswa. Selain itu, kecemasan yang subjek alami pun berkurang ketika ia menggunakan teknik-teknikyang diajarkan dalam CBT. Temuan ini sejalan dengan penelitian oleh de Hulu, Sportel, Nauta, dan Jong (2017) yang membuktikan CBT efektif membantu remaja mengatasi kecemasan yang dihadapi. Gambaran hasil intervensi setiap sesi disajikan dalam tabel 2 .
Secara umum, terdapat perbedaan kondisi subjek saat sebelum dan setelah diberikan intervensi CBT. Sebelum intervensi, subjek merasa selalu memendam pikiran dan perasaannya kepada orang lain. Subjek pun merasa bahwa ia cenderung memiliki aturan dan asumsi yang tidak bermanfaat dan tidak realistis. Selain itu, ia merasa memiliki banyak pikiran negatif. Sayangnya, ia tidak tahu bagaimana mengendalikan pikiran negatif tersebut sehingga ia kerap mengabaikannya. Setelah diberikan intervensi, subjek mampu mengungkapkan pikiran dan perasaan yang selama ini ia pendam. Subjek juga mampu menyebutkan keyakinan diri yang negatif, aturan/ asumsi yang tidak bermanfaat dari dirinya, dan pikiran ototmatis negatif yang muncul pada situasi tertentu. Kemudian ia dapat mengidentifikasi jenis distorsi kognitif yang ia miliki. 
Tabel 2. Hasil Evaluasi Setiap Sesi Intervensi

\begin{tabular}{|c|c|}
\hline Tujuan & Kegiatan \\
\hline \multicolumn{2}{|r|}{ Sesi 1 : Cognitive Model and Cognitive Distortions (60-120 menit) } \\
\hline $\begin{array}{l}\text { Mengetahui pola inter- } \\
\text { aksi pikiran, emosi, dan } \\
\text { perilaku }\end{array}$ & $\begin{array}{l}\text { - Terapis mempersilakan klien menjelaskan situasi hidup saat ini terkait masalah psi- } \\
\text { kologis yang dihadapi } \\
\text { - Terapis bersama klien membuat daftar prioritas masalah yang akan menjadi fokus } \\
\text { terapi berdasarkan simptom spesifik, perilaku, dan masalah yang menetap. } \\
\text { - Terapis menjelaskan pengaruh pikiran terhadap emosi dan perilaku hingga serta pen- } \\
\text { garuhnya terhadap keyakinan dasar dan distorsi koginitif }\end{array}$ \\
\hline $\begin{array}{l}\text { Mengidentifikasi core } \\
\text { belief (keyakinan dasar) }\end{array}$ & $\begin{array}{l}\text { - Terapis menjelaskan apa yang dimaksud dengan core belief } \\
\text { - Terapis menggali keyakinan dasar klien yang negatif tentang dirinya } \\
\text { Terapis menjelaskan dampak adanya keyakinan negatif yang memunculkan distorsi } \\
\text { kognitif }\end{array}$ \\
\hline $\begin{array}{l}\text { Mengidentifikasi distorsi } \\
\text { kognitif }\end{array}$ & $\begin{array}{l}\text { - Terapis memberikan pemahaman kepada klien mengenai distorsi kognitif dan berag- } \\
\text { am jenisnya } \\
\text { - Terapis meminta klien mengidentifikasi kesalahan-kesalahan berpikir yang dimiliki }\end{array}$ \\
\hline $\begin{array}{l}\text { Mengidentifikasi aturan } \\
\text { dan asumsi }\end{array}$ & $\begin{array}{l}\text { - Terapis bertanya apa yang klien ketahui tentang aturan dan asumsi. } \\
\text { - Terapis meminta klien menuliskan aturan dan asumis yang dimiliki klien selama ini, } \\
\text { yang menjadi panduan dalam bertingkah laku sehari-hari; jika... maka, harus... } \\
\text { - Terapis menanyakan aturan/asumsi mana yang menurut klien bermanfaat dan tidak } \\
\text { bermanfaat baginya }\end{array}$ \\
\hline $\begin{array}{l}\text { Mengidentifikasi pikiran } \\
\text { otomatis }\end{array}$ & $\begin{array}{l}\text { - Terapis meminta klien memikirkan saat dimana ia memiliki emosi negatif dalam satu } \\
\text { atau dua minggu terakhir ini; misalnya cemas, sedih, panik, tidak berharga. Lalu apa } \\
\text { yang dipikirkan pada waktu itu. } \\
\text { - Terapis menanyakan apa reaksi yang muncul akibat dari pikiran otomatis yang negatif } \\
\text { tersebut serta manfaat yang diperolehnya }\end{array}$ \\
\hline Tugas rumah & $\begin{array}{l}\text { - Klien diminta mempelajari kembali materi hari ini melalui lembar kerja 'Cognitive } \\
\text { Model' dan 'Cognitive Distortions' } \\
\text { - Klien diberikan lembar 'Challenging Thought' untuk membantu menantang pikitan } \\
\text { negatif dalam dirinya }\end{array}$ \\
\hline $\begin{array}{l}\text { Evaluasi sesi } 1 \\
\text { - Mengetahui insight } \\
\text { yang klien dapatkan }\end{array}$ & $\begin{array}{l}\text { - Terapis meminta klien menyampaikan apa yang diperoleh dari sesi terapi yang diikuti } \\
\text { - Terapis mencatat perasaan dan cerita yang disampaikan klien }\end{array}$ \\
\hline
\end{tabular}

Sesi 2 : Cognitive Restructuring (60-120 menit)

Merestrukturisasi kogni- • Terapis menanyakan kepada klien apakah sudah mengerjakan tugas rumah atau belum tif yang dimiliki dan sejauh mana perubahan yang terjadi dalam dirinya

- Terapis memberi kesempatan kepada klien untuk menceritakan perasaan dan pikirannya terkait pikiran otomatis yang negatif serta aturan dan asumsi yang dimiliki

- Terapis menggunakan teknik-teknik yang dapat membantu klien mengevaluasi pikiran negatif yang dimiliki; pertanyaan sokratik dan mengajukan pertanyaan-pertanyaan kepada klien sebagai cara menemukan bukti dan mengevaluasi pikiran klien

- Terapis meminta klien memikirkan alternatif pikiran yang lebih positif dan membandingkannya dengan pikiran negatif yang sebelumnya.

- Hal yang sama juga dilakukan untuk menantang aturan dan asumi lama. Klien diminta membuat aturan dan asumsi baru yang lebih seimbang, realistis, dan fleksibel menggantikan aturan dan asumsi lamanya

Tugas rumah

- Terapis menjelaskan tugas klien dan memberi contoh pengerjaan pada lembar kerja 'Putting Thought on Trial'

- Klien diminta membuat catatan pikiran yang muncul pada beragam situasi beserta perasaan dan perilaku yang menyertai dalam lembar 'Thought Records'

- Klien diminta membuat catatan pikiran otomatis dan aturan/asumsi yang baru

Evaluasi sesi 2

- Terapis meminta klien menyampaikan apa yang diperoleh dari sesi terapi yang diikuti

- Mengetahui insight

- Terapis mencatat perasaan dan cerita yang disampaikan klien yang klien dapatkan 
Sesi 3 : Akivitas Aspek Positif dalam Diri (60-120 menit)

\begin{tabular}{|c|c|}
\hline $\begin{array}{l}\text { Aktivasi aspek positif } \\
\text { dalam diri } \\
\text { - Membantu klien } \\
\text { menemukan } \\
\text { aspek-aspek positif } \\
\text { dan kekuatan dalam } \\
\text { dirinya }\end{array}$ & $\begin{array}{l}\text { - Terapis menanyakan kepada klien apakah sudah mengerjakan tugas rumah atau } \\
\text { belum dan sejauh mana perubahan yang terjadi dalam dirinya } \\
\text { - Terapis meminta klien menceritakan perbedaan diri klien yang sekarang dan yang } \\
\text { dulu, terutama dalam mengandalkan kekuatan dirinya tersebut } \\
\text { - Terapis meminta klien menceritakan mimpinya di masa depan dan apa saja penca- } \\
\text { paian yang ia inginkan serta bagaimana cara ia mencapainya. } \\
\text { - Terapis melakukan review atas hal-hal positif dari klien. Klien dapat menambahkan } \\
\text { jika perlu, terutama aspek-aspek yang berkaitan dengan pencapaian akademik. } \\
\text { - Terapis meminta klien menceritakan pengalaman pada masa lalu yang membuatnya } \\
\text { berubah dan dapat mengandalkan kekuatan dirinya }\end{array}$ \\
\hline $\begin{array}{l}\text { Aktivasi perilaku positif } \\
\text { Membantu klien } \\
\text { menemukan kegia- } \\
\text { tan yang menguat- } \\
\text { kan aspek positif } \\
\text { pada dirinya }\end{array}$ & $\begin{array}{l}\text { - Terapis mereview latihan relaksasi pernafasan yang telah diajarkan } \\
\text { - Terapis meminta klien menuliskan seluruh kegiatan yang membuatnya rileks, tenang, } \\
\text { nyaman, dan berpikir positif. } \\
\text { - Klien diminta untuk menghubungkan kegiatan-kegiatan tersebut dengan aspek positif } \\
\text { yang ada pada dirinya }\end{array}$ \\
\hline Tugas rumah & $\begin{array}{l}\text { - Klien diminta melakukan relaksasi yang telah diajarkan hingga pertemuan selanjutnya } \\
\text { - Klien diminta membuat cerita hidup yang membuatnya menemukan makna dari dir- } \\
\text { inya dalam lembar Life Story' } \\
\text { Klien membuat 'Gratitude Journal' dan 'Self-esteem Journal' selama sepekan atau hing- } \\
\text { ga pertemuan selanjutnya }\end{array}$ \\
\hline \multirow[t]{2}{*}{$\begin{array}{l}\text { Evaluasi sesi } 3 \\
\text { - Mengetahui insight } \\
\quad \text { yang klien dapatkan }\end{array}$} & $\begin{array}{l}\text { - Terapis meminta klien menyampaikan apa yang diperoleh dari sesi terapi yang diikuti } \\
\text { - Terapis mencatat perasaan dan cerita yang disampaikan klien }\end{array}$ \\
\hline & \\
\hline $\begin{array}{l}\text { Evaluasi dan Asesmen } \\
\text { Akhir } \\
\text { - Mengevaluasi } \\
\text { keseluruhan sesi, } \\
\text { mendiskusikan hasil } \\
\text { intervensi, asesmen } \\
\text { akhir, dan terminasi }\end{array}$ & $\begin{array}{l}\text { - Terapis meminta klien menceritakan tentang efektivitas program intervensi, melipu- } \\
\text { ti: perubahan cara pandang, pemahaman akan diri, perbedaan sebelum dan sesudah } \\
\text { mengikuti intervensi, dan penerapan latihan yang diberikan di kemudian hari } \\
\text { - Terapis memberikan apresiasi kepada klien atas keberhasilan yang sudah dicapai sela- } \\
\text { ma mengikuti intervensi } \\
\text { Terapis menanyakan kepada klien tentang dan evaluasi secara keseluruhan sesi terapi }\end{array}$ \\
\hline
\end{tabular}

Subjek menyadari bahwa kecemasan yang seringkali muncul selama ini berasal dari pikiran-pikiran negatif dan asumsi/ aturan yang ia ciptakan sendiri dan belum terbukti benar. Subjek pun menyadari bahwa ia harus berpikir tentang suatu situasi secara lebih seimbang dan adil. Setelah intervensi, ia mulai dapat menggunakan teknik-teknik untuk menghadapi pikiran-pikiran negatif yang muncul. Dalam praktik sehari-hari, ketika subjek dihadapkan pada suatu situasi yang membuatnya berpikir negatif lalu membuatnya cemas, misalnya saat akan ujian atau diberikan umpan balik negatif, subjek sudah dapat menerapkan teknik yang diajarkan. Ia melihat suatu situasi dengan lebih adil dan seimbang kemudian menggunakan beberapa teknik relaksasi untuk membantu mengurangi kecemasan yang dirasakan.

Terdapat beberapa faktor yang mendukung keberhasilan intervensi. Pertama, sikap subjek yang kooperatif. Subjek mau bekerja sama selama mengikuti intervensi sehingga keseluruhan proses intervensi berjalan lancar. Subjek selalu hadir tepat waktu pada setiap sesi yang telah disepakati. Subjek juga dapat memenuhi tugas yang diberikan selama sesi serta selalu menyelesaikan tugas rumah yang diberikan. Kedua, subjek memiliki keinginan untuk berubah. Ia pun menunjukkan komitmen dengan mau mengikuti intervensi hingga akhir. Ketiga, adanya hubungan baik yang terbangun antara peneliti dan subjek. Hal ini membuat 
subjek mau membuka diri tentang masalah yang dihadapi, mengungkapkan masalah dan kesulitan yang dihadapi, serta tidak terlihat sungkan dalam mengungkapkan pendapatnya. Ketiga faktor ini sejalan dengan yang dikatakan Rector (2010) bahwa keberhasilan terapi tidak hanya ditentukan oleh terapis tetapi juga oleh klien. Klien perlu terbuka dan mau berdiskusi tentang pikiran, keyakinan, dan perilakunya kepada terapis serta mau berpartisipasi dalam latihan yang diberikan di setiap sesi, termasuk mengerjakan tugas rumah. Jadi, terapis dan klien perlu saling bekerja sama.

Faktor lain yang juga turut mendukung keberhasilan intervensi adalah setting pelaksanaan intervensi. Tempat yang digunakan selama intervensi adalah di ruang pemeriksaan Klinik Terpadu Fakultas Psikologi Universitas Indonesia. Ruangan tertutup, tidak ada orang lain yang terlibat selain subjek dan peneliti, jauh dari kebisingan, memiliki pencahayaan dan suhu yang cukup, serta sirkulasi udara yang baik. Hal ini membuat subjek merasa nyaman, aman, terjamin privasi dan kerahasiaanapa yang dibicarakan subjekselama intervensi. Faktor ini perlu diperhatikan karena temuan penelitian oleh Islamiah, Daengsari, dan Hartiani (2015) menunjukkan bahwa setting pelaksanaan intervensi dengan suasana yang kurang nyaman, sirkulasi udara yang kurang baik, ruangan yang bising, tidak tertutup, dan kurang kondusif dapat menghambat pelaksanaan intervensi.

Selain faktor pendukung, terdapat faktor yang menjadi penghambat dalam intervensi, diantaranya: keterbatasan waktu pertemuan dengan subjek sehingga pembahasan materi dan tugas dinilai kurang optimal. Waktu yang terbatas pun membuat program tidak dapat ditindaklanjuti secara berulang untuk memantau konsistensi perubahan pada subjek. Selain itu, dapat dikatakan subjek lebih banyak mendalami materi dan mengerjakan tugas yang diberikan kepadanya di rumah. Hal ini membuat subjek tidak dapat berdiskusi langsung dengan peneliti ketika menemui kesulitan dalam memahami materi maupun mengerjakan tugas sehingga pengerjaan tugas dinilai kurang optimal.
Selanjutnya, peneliti melihat adanya keterbatasan dalam penelitian ini. Pertama, latihan praktik untuk melakukan kegiatan positif dan relaksasi dinilai kurang terpantau dengan baik. Peneliti tidak memberikan lembar kerja atau instrumen tambahan yang dapat dengan baik memantau perkembangan aktivitas dan perubahan perilaku subjek. Kedua, subjek bersedia mengikuti intervensi ini dengan tanpa diketahui orang tua maupun teman. Padahal keluarga dan teman menjadi faktor eksternal yang juga penting dalam pembentukan self-esteem seseorang. Menurut Santrock (2011), self-esteem merupakan suatu komponen kepribadian yang berkembang melalui proses interaksi dengan keluarga, orang tua, teman sebaya, dan orang lain yang bermakna bagi individu. Jika subjek tidak mendapat dukungan dari lingkungan sementara ia mendapat perlakuan yang sama, seperti dibanding-bandingkan, diremehkan, dan tidak diberi apresiasi yang cukup, subjek dikhawatirkan akan kembali pada kondisi sebelum intervensi (relapse). Apalagi dalam kasus ini, kurangnya dukungan dan penerimaan orang tua terhadap subjek merupakan penyebab utama rendahnya self-esteem subjek.

Coopersmith dan Rosenberg (dalam Mruk 2006) menjelaskan pentingnya dukungan dan penerimaan orang tua terhadap perkembangan self-esteem seorang anak. Dukungan orang tua melalui pemberian semangat secara emosi dan materi serta kehadiran dan keterlibatannya dalam aktivitas keseharian anak, akan membantu mengembangkan self-esteem anak yang positif. Orang tua yang kasar, sering mengkritik, tidak menerima kelebihan dan kekurangan anak seutuhnya, dapat menjadi faktor yang menurunkan self-esteem anak (Coopersmith; Rosenberg, dalam Mruk 2006). Mendukung hal tersebut, temuan dari Martínez dan García (2007) turut menegaskan bahwa orang tua yang memiliki kehangatan, responsivitas, dan keterlibatan yang tinggi, dikombinasi dengan kontrol yang juga tinggi, akan mendorong optimalisasi penyesuaian diri pada anak-anak.

Agar dampak positif dari intervensi dapat terjaga, peneliti memberikan beberapa 
rekomendasi untuk subjek, diantaranya: terus melatih teknik-teknik untuk merekonstrusksi kognitif yang telah diperoleh, mengingat kembali pikiran otomatis dan aturan/asumsi baru yang telah dibuatnya dan menerapkannya dalam kehidupan sehari-hari, menggunakan teknik relaksasi yang diajarkan untuk menghalau perasaan negatif yang muncul dalam berbagai situasi, terutama kecemasan yang muncul pada situasi tertentu, mempertahankan komitmen untuk berubah menjadi lebih baik maupun perilaku positif yang telah terbentuk dan, mencoba lebih terbuka kepada orang lain dengan mengungkapkan dan mengekspresikan pikiran dan perasaan yang dimiliki agar masalah dihadapi tidak terpendam dan bisa memperoleh sudut pandang berbeda dari orang lain; 6) melakukan aktivitas untuk mencari pengalaman dan pergaulan yang dapat meningkatkan kepercayaan diri ataupun hal positif darinya. Misalnya, seminar/workshop/konferensi, social project, freelance, ataupun mengikuti klub yang dapat meningkatkan keterampilan public speaking.

\section{SIMPULAN}

Berdasarkan hasil yang diperoleh dalam penelitian studi kasus ini, diketahui bahwa CBT efektif dalam meningkatkan self-esteem remaja. CBT membantu mengubah keyakinan diri, pikiran, dan emosi subjek yang cenderung negatif melalui teknik-teknik restrukturisasai kognitif dan relaksasi yang diajarkan. Hasil penemuan ini menguatkan penelitian terdahulu tentang efektivitas CBT, terutama dalam menambah khasanah penelitian CBT pada remaja dengan self-esteem rendah. Adanya teknik relaksasi yang membantu subjek mengelola emosinya menjadi lebih positif, menjadi nilai tambah dalam intervensi. Beberapa faktor pendukung pada pelaksanaan intervensi turut berkontribusi dalam keberhasilan intervensi.

\section{DAFTAR PUSTAKA}

Acharya P. R., \& Chalise, H. N. (2017). Self-esteem and Academic Stress among Nursing Students. Kathmandu University Medical Journal, 13(4), 298. https://doi.org/10.3126/kumj. v13i4.16827

Branden, N., (1969). The Psychology of Sel-Esteem. New York: Nash

Coopersmith, S. (1967). The antecedents of Self-esteem. San Fransisco: Freeman and Company

Corey, G. (2009). Theory and Practice of Counseling and Psychotherapy. Belmont California: Brooks/Cole Publishing Company.

Corsini, R.J \& Wedding, D. (2011). Current Psychoterapies (9th edition). Belmont: Brooks/Cole

Della. (2012). Cognitive Behavior Therapy untuk Meningkatkan Self-esteem pada Mahasiswa Universitas Indonesia yang Mengalami Distres Psikologis. Tesis, tidak diterbitkan. Universitas Indonesia, Depok

Guindon, M. H. (Ed.). (2010). Self-esteem Across the Lifespan: Issues and Interventions. New York: Routledge.

Islamiah, N., Daengsari, D. P., \& Hartianti, F. (2015). Cognitive Behavior Therapy untuk Meningkatkan Self-esteem pada Anak Usia Sekolah. Jurnal Ilmu Keluarga dan Konsumen, 8(3), 142-152.https://doi.org/10.24156/jikk.2015.8.3.142

James, W. (1980). The Principles of Psychology, Vol. 2. NY, US: Henry Holt and Company

Martínez, I., \& García, J. F. (2007). Impact of Parenting Styles on Adolescents' Self-esteem and Internalization of Values in Spain. The Spanish Journal of Psychology, 10(02), 338-348. https://doi.org/10.1017/S1138741600006600 
Mruk, C. J. (2006). Self-esteem Research, Theory, and Practice: Toward a Positive Psychology of Self-esteem. New York: Springer Pub. Retrieved from http://public.eblib.com/choice/ publicfullrecord.aspx? $\mathrm{p}=291344$

Mulyadi, S., Rahardjo, W., \& Basuki, A. M. H. (2016). The Role of Parent-child Relationship, Selfesteem, Academic Self-efficacy to Academic Stress. Procedia - Social and Behavioral Sciences, 217, 603-608. https://doi.org/10.1016/j.sbspro.2016.02.063

Newman, B.M. \& Newman, P.R. (2015).Development through life: A psychology approach twelfth edition. Canada: Nelson Education, Ltd.

Poerwandari, K. (2011). Pendekatan Kualitatif untuk Penelitian Perilaku Manusia. Depok: LPSP3 Fakultas Psikologi Universitas Indonesia.

Rector, N.A. (2010) Cognitive-behavioural therapy: an information guide. Canada : Centre for Addiction and Mental Health

Rosenberg. (1965). Rosenberg Self-esteem Scale.

Santrock, J. W. (2011). Educational Psychology (5th Ed.). New York: Mc Graw Hill

Sartaj, B. \& Aslam, N. (2010). Role of Authoritative and Authoritarian Parenting in Home, Health and Emotional Adjustment. Journal of Behavioural Sciences, 20,(1), 2010

Stallard, P. (2002). Think Good - Feel Good: A Cognitive Behavior TherapyWorkbook for Children and Young People. West Sussex: John Wiley \&Sons, Ltd.

Therapist Aid LLC. (2017). Therapist Aid: Worksheets and Tools for Mental Health Professional. Diakses dari therapistaid.com pada tanggal 23 September 2017 